\title{
Watershed Degradation in the Bamendjin Area of the North West Region of Cameroon and Its Implication for Development
}

\author{
Sunday Shende Kometa ${ }^{1} \&$ Mathias Ashu Tambe Ebot ${ }^{1}$ \\ ${ }^{1}$ Department of Geography, FSMS, University of Buea, Cameroon \\ Correspondence: Sunday Shende Kometa, Department of Geography, FSMS, University of Buea, Cameroon. \\ E-mail: shendeK@hotmail.com
}

Received: July 10, 2012 Accepted: August 11, 2012 Online Published: August 24, 2012

doi:10.5539/jsd.v5n9p75 URL: http://dx.doi.org/10.5539/jsd.v5n9p75

\begin{abstract}
It is indeed a paradox that even with favourable natural endowments such as fertile soils and abundant surface water resources, some rural communities and regions still reflect major levels of poverty, food insufficiency, limited water supplies and water-related health problems. To ensure stability in food production and sustain food sufficiency in areas where local economies entirely depend on farming and the natural state of the environment, it is important to investigate the indications and implications of environmental degradation. Through the application of relevant field methods for data acquisition and analyses, the paper examines and proposes recommendation where ..... of the degradation of the Bamendjin Catchment area, which is located within the fertile volcanic province of the North West Region of Cameroon. The results reveal that poor land use have ushered in profound degradation of this watershed. This paper also provides the tools needed to improve on the perception and attitude of the inhabitants towards the exploitation of this watershed and their local environment in general.
\end{abstract}

Keywords: watershed, catchment area, degradation, Bamendjin, food security

\section{Introduction}

Watersheds are generally considered as points of development especially in countries which rely on water dependent activities. A major problem confronting watersheds remains the increase in human population and land use mutations, which sets in to degrade watersheds. The implications on communities concerned are usually grave - the decline in water quality and quantity which translates into the upsurge of water borne diseases and a drop in agricultural production. The Bamendjin Area in the Bamenda Highlands of Cameroon is an agro-economic haven with enormous potentials for sustainable food production. As Lambi (1999) points out, the swamps and the dam in the Bamendjin watershed constitute an abundantly vast 'water empire'. The diversified physical terrains of the Bamendjin area have determined the different types of occupational land use systems with consequent agricultural intensification (Lambi, 1999). The varied nature of the physical and human landscape thus, constitutes the framework for the spatial processes which considerably account for the degradation of the watershed. However, the increasing human population, coupled with the scarcity of favourable land for farming, grazing and construction of settlements appear to be the drivers of watershed degradation. Furthermore, it is worth noting that the long cycles of poverty in the North West Region with approximately 365,352 poor people intensifies the watershed degradation process (Tanga \& Fonchingong, 2009). The case of the region 'is remarkable due to its high population density and a rural economy that depends on subsistence agriculture which yields little income and can barely sustain livelihoods' (Tanga \& Fonchingong, 2009).

Watersheds are zones of conflicts because land users have different goals for the available natural resources. In this area, there is the encroachment of farmers into traditional grazing lands and straying of animals onto farmlands. These have resulted in social and economic conflicts which undermine efforts to improve the lives of large numbers of the poor who depend on these resources for their survival and economic well-being. Since the population in this watershed has been growing fast, there is need for sufficient water supplies. Water scarcity and contamination have thus, remained issues of major concern and a hindrance to development. The drop in farm produce (in terms of quality and quantity) reduces the income-generating power of the population and retards their development. Biodiversity provides material wealth. These aesthetic rewards are threatened by the general 
losses imposed on the landscape by crop cultivation and animal rearing. This is an unfortunate trend because vegetal destruction means most living things sustained by this habitat either die or do seek asylum elsewhere.

The Bamendjin Area constitutes a major watershed which has been very useful to the local population as they depend on it in the pursuit of their developmental activities (water supply, agriculture, grazing and fishing). However, this watershed has been witnessing remarkable degradation which stems largely from population change, the multiplication of poor and incompatible land use practices and the increasing shortage of land. This scenario has been sustained and aggravated by poverty which is a major driver of the degradation of natural resources. The implications of such degradation are already being felt in this area as developmental activities have been constrained. Evidence of watershed degradation and its implications on development could be reflected in the drop in agricultural production and fishing. Indicators such as the decline in water quality, quantity, the increase in water-related illnesses and the increase in food prices are active issues which draw attention for questions on the environmental quality and degradation.

Other issues such as farmer-grazer conflicts, overgrazing, the seasonality of streams and scarcity of potable water in the dry season are just part of the chain of problems originating from the degradation of the watershed. The irony is thus obvious, and justifies the search for prompt answers and solutions, considering the high yearly rainfall amount of about $2000 \mathrm{~mm}$ and the abundance of surface water sources on the one hand and the ephemeral nature of streams on the other hand. The introduction of mechanized rice cultivation by the Upper Nun Valley Development Authority (UNVDA) has also contributed enormously with respect to enhanced deforestation and the loss of favourable land for indigenous and subsistence farming systems. In the light of the problems addressed so far, the paper attempts to examine the problem of watershed degradation in the Bamendjin area and its development implications on the population of this area. It attempts to illustrate the relationship between the reduction in the quality of the environment and economic indicators such as increases in food prices and the reduction in farm produce yields. It equally looks at the main economic activities of the area and the resources upon which these activities are based.

In spite of the impressively increasing awareness on environmental issues, the individual and overall efforts of the world's leading economics, academics and related institutions still lag way behind the rate of degradation of the environmental resource base. In developing countries, the increasing demands of the astronomical population growth compounded with the scarcity of land and persistent aggressive cycles of poverty are compelling people to encroach and degrade watersheds in their search for farming and settlement land. In Cameroon, agriculture is the foundation of the country's economy, with rural areas being the major food producing centres. Ironically however, a majority of the poor live in the rural areas.

\section{Methods and the Study Area}

The degradation of the Bamendjin watershed has had far reaching implications for agricultural development. In order to assess the extent of this, the study was conducted based on field surveys, measurements of slope angles, administration of questionnaires and interviews, and consultation of relevant documented data particularly from the North West Delegation of the Ministry of the Environment and Forestry, Upper Nun Valley Development Authority (UNVDA). Slope angels enable us to evaluate the steepness of the slopes and their uses. The local population provided our target population and they provided their opinion on the causes of the degradation of this watershed and their views on the causes on the declining food production in the whole region. They also provided estimates of their year productions in tons and the prices of the various basic commodities sold in the local markets around this region. Rangeland was also visited to find out possible indicators of land degradation such as the presence of the brachen fern. Secondary data was obtained from relevant publications, public health institutions and the Upper Nun Valley Development Authority (UNVDA) which is principally involved in mechanized rice farming in the area.

Interviews conducted to some officials of the Kilum-Ijim Forest Projects, some officials of the UNVDA complimented the information on forest degradation, crop production particularly rice and the evolution in the prices over time. From the officials of the Kilum-Ijim Forest project and the MINEF, information on the extent of the degradation of this watershed was acquired and the successes recorded so far on conserving this watershed. Field surveys provided us with an opportunity to observed land use, farming methods, deforestation and the strategies put in place by the local population and the conservation agencies in protecting this watershed and improving on food production. The weather station of the UNVDA situated at Babungo provided us with climatic data for the region. Topographic maps, soil maps and vegetation maps provided information on the relief of the area, soil types and vegetation evolution. Using correlation analysis we brought out the link between this watershed degradation, food production and economic development of the region as a whole. 
This area is located within an extensive plateau which is surrounded by the Bamboutous Massif, the Sabga and Kom Plateaux, Mt Oku, the Kilum Massif and the broad ljim Ridge. It is worth noting that the Kilum Massif and ljim Ridge are the major highlands on which is found the watershed of the River Nun which flows down to the Ndop plain. The surrounding ridges have a broad opening south into the Bamoum plateau, which is an outlet to the Nun waters that drain the Bamendjin reservoir. The area is located from longitude $10^{\circ} 20^{\prime} \mathrm{E}$ to $16^{\circ} 40^{\prime} \mathrm{E}$ and latitude $5^{\circ} 40^{\prime} \mathrm{N}$ to $6^{\circ} 20^{\prime} \mathrm{N}$ of the equator (Figure 1). It has a monotonously flat to undulating landscape whose topography is broken either by ancient granitic residual hills or volcanic plugs. The Ndop plain is studded by numerous wetlands and pockets of salt springs into which a host of tributaries unite to form the River Nun downstream (Lambi, 2001).

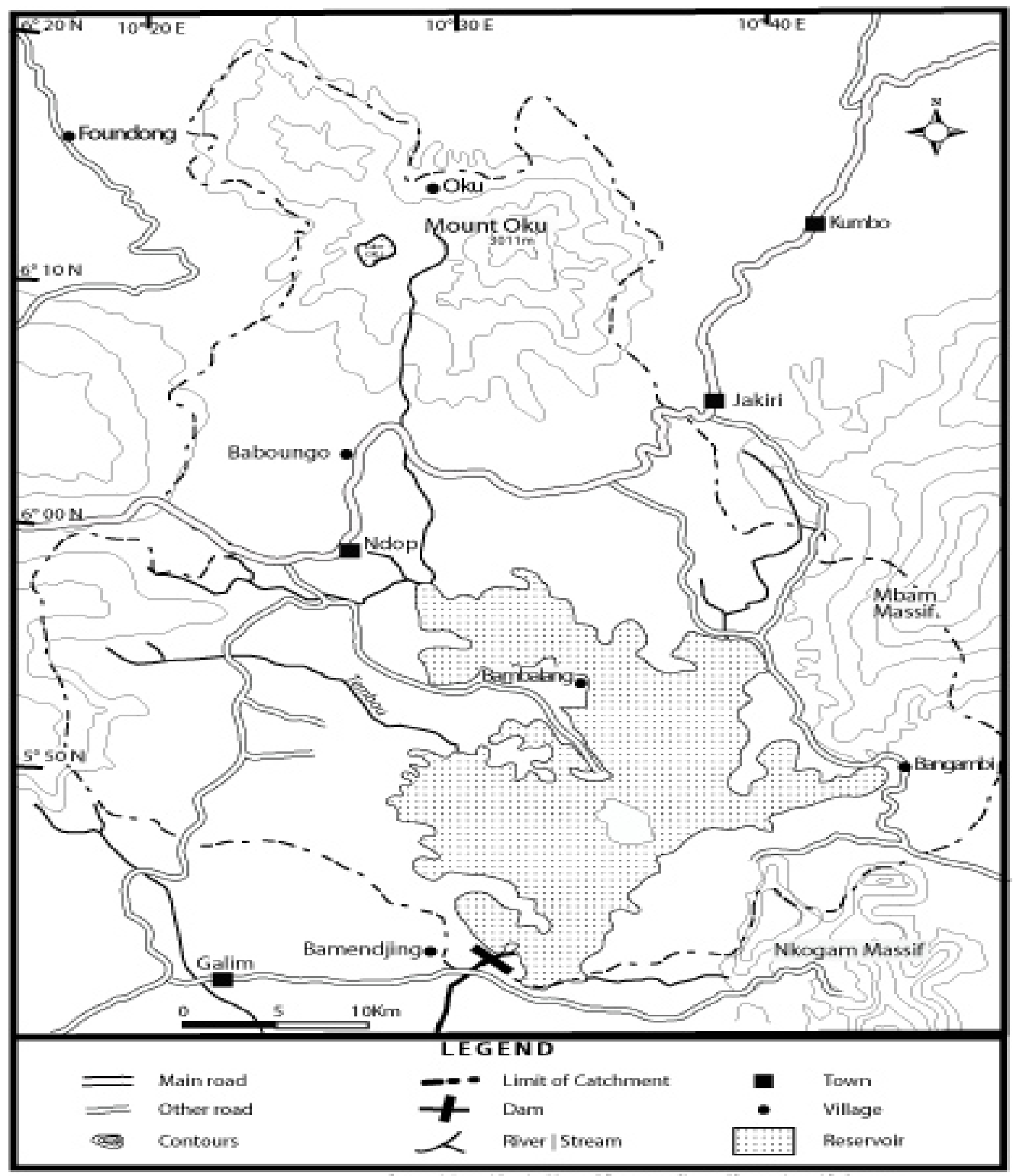

Figure 1. Location of the Bamendjim Catchment Area in the north west region of Cameroon

The Mount Oku (3011) serves as the main watershed for the whole of this region. It is the main source of rivers and streams in the Region (Figure 1). The Bamendjin Dam, meant to boost the main electricity production plant on the River Sanaga at Edea, is built across the River Nun. Another important hydrological feature in this region is the Lake Oku which occurs in a steep sided caldera which is now threatened by sedimentation. The steep and much dissected slopes of the mountain lead to a considerable amount of surface drainage. The crystalline rocks 
have the propensity to store water which seeps out at lower elevations as springs. The upland areas bear mostly streams that take their rise from the high plateau.

\section{Degradation of the Watershed}

The analysis of slope gradients revealed that the maximum basin relief is $1.857 \mathrm{~m}$, with a mean slope of $1.8 \%$. The slopes were categories as follows; flat to gently sloping (1-6\%) on the alluvio-colluvvial deposits at Bamunka; moderately steep slopes with granitic soils and an undulating topography (7-25\%) around the escarpments right down to the foot hills; and the high altitude basaltic and trachytic soils on very steep slopes from 26-55\%. The soils along these slopes are skeletal and susceptible to erosion. The tertiary basalts and trachytes when weathered act as lubricating surfaces for landslides over most of the slopes. Grazing is concentrated on the summits and plateaus. Basaltic soils occur in the highlands in Bab 1, Babungo, Sabga, Bamessing and Babanki-Tungo. These basaltic soils and the moderate micro-climate in these highlands have favoured the cultivation of crops like Irish potatoes.As some of these highlands are used for grazing, the areas south of this region are intensely cultivated. Consequently, farmers are sustained by the growing and marketing of crops and the raising of livestock. In the lower slopes around Sabga, Balikumbat and Babungo which are partly underlain by basement complex rocks with relatively poor soils, livestock rearing is a dominant activity. Since nutrients are easily washed off from these soils, it is necessary for the use of fertilizers, especially in areas where indigenous adaptations have failed to restore soil fertility.

Scarcity of favourable land for farming due to increasing population pressure and degradation of soil and vegetation have contributed to watershed degradation. The landscape of this area particularly the Kilum-Ijim mountane forests have diminished significantly (Figure 2). The degradation of these forests that make up the major watershed for the River Nun has been accompanied by diminishing species of trees, birds and more especially, certain animals. The reduction in the number of animals or particular species over time is as a result of the degradation of some parts of the watershed ecosystem. The reduction in pasture/fresh grass for cattle result, from overgrazing due to the increasing number of animals and human population and pressure on available land. This pressure has resulted in the encroachment into marginal areas and degradation of the watershed as reflected in the high rates of deforestation, and soil erosion. The reduction in soil fertility due to soil erosion has resulted in a drop in agricultural output over time. This is indicated by the continuous increase in the prices of food items (Table 2). The high prices are also caused by the use of fertilizers and other intensive forms of farming, which step up the cultivation costs. Also the number of people keeping livestock is increasing (MINEPIA, 2006). The concentrations of these herds on the highlands have not only degraded the vegetal cover but have also increased water tracks, attendant gullies and runoffs. When cattle trample and compact the soils, it hinders infiltration.

On the other hand, high infiltration over many ploughed farms favours saturation of the soil and consequently slumping. Man needs the soil for agriculture and within this area, he clears, burns the grass and also graze, his animals. Each of these activities in the area exposes the soil to agents of erosion. Runoff on slopes erodes the soil and creates deep gullies, some which measure up to $80 \mathrm{~m}$ long, $50 \mathrm{~cm}$ wide and about $30 \mathrm{~cm}$ deep. On some fairly overgrazed slopes on the western part of this area, it was estimated that more than one entimeter of topsoil is removed every year. In some areas, can be seen "hardpans" (or duricrust). When the rains come, this crust reduces infiltration and the runoff consequently carries away the top soil, nutrients and organic matter.

In 1963, the Kilum-Ijim forest covered an area of about 20,000 hectares. Due to human encroachment it was reduced to about 11,400 in 1990 (MINEF, 2000). This massive deforestation reduced the adult population of the prunus trees by about $80 \%$ since its bark is used to produce pharmaceutical products. With the intervention of some conservation organizations and the local authorities, this encroachment was checked. Over the past decade, regeneration of the forest, re-enforcement of the Cameroon forestry law and conservation strategies have helped to increase the forest cover to about 15,000 hectares. The marked decrease in the original forest wood as against theeucalyptus trees has been a pointer to the degradation of the Kilum-Ijim forest, which is the major watershed for the River Nun. Some streams have now become ephemeral, while others have witnessed a significant drop in flow. The cutting down of trees for cultivation has deprived the region of its dense forest vegetation which once stood as a check to the erosive power of water. The fluctuating nature of the hydroelectric energy at Edea which is empowered by the River Nun is largely attributed to the increasing seasonality of the stream. This situation is worsening from year to year. The 1996/1997 incidence of the cholera epidemic in the Babungo locality was believed to have resulted from the fact that the people downstream drank toxic chemicals that were used upstream to bathe cattle against ecto-parasites such as ticks. 


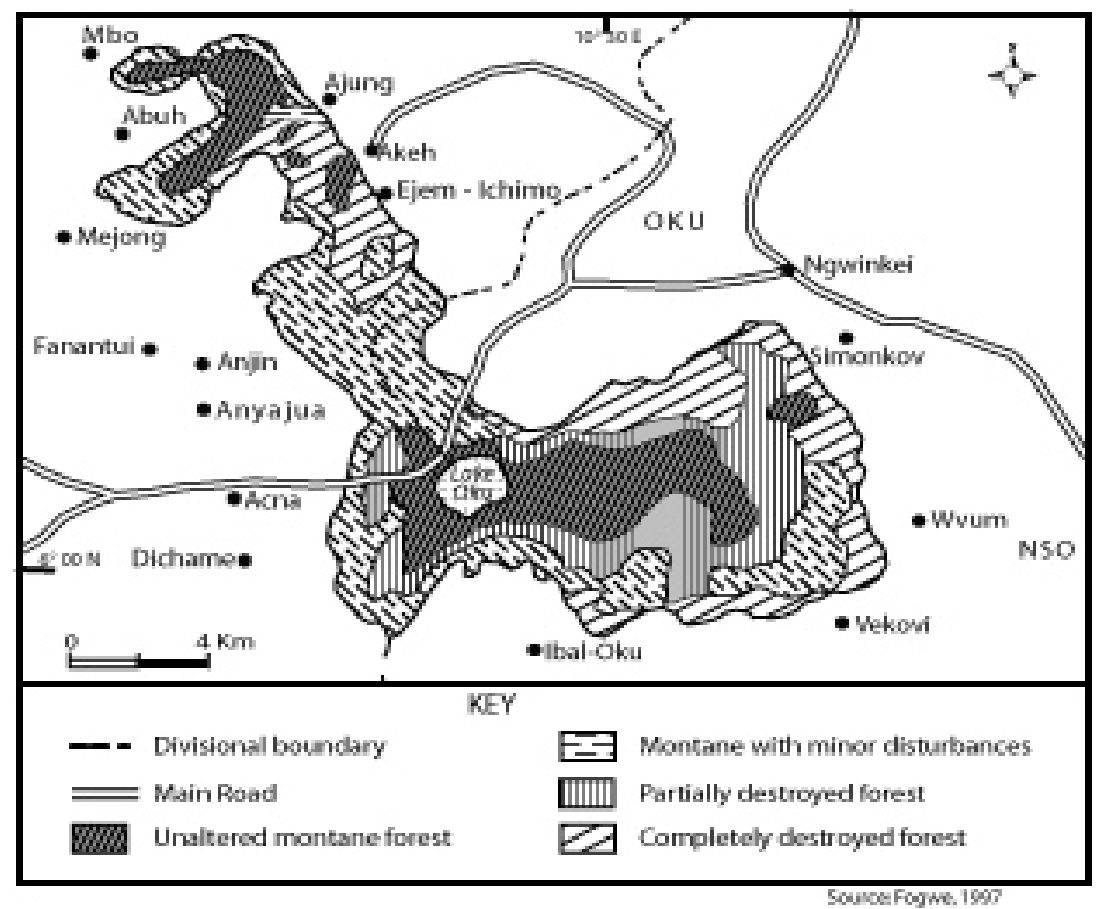

Figure 2. The Degradation of the kilum-ijim community forest

Poisonous tree barks are also frequently used here for fishing. This degrades the water quality. However, the drop in the volume of water should not be totally attributed to deforestation but also on the gradual increase in the number of eucalyptus plantations given their high ability to consume water. A mature eucalyptus tree uses about 29 gallons of water per day which is the same quantity required to sustain an average household of six in cooking, drinking, bathing and laundry for three days (The Cameroon Post No. 0064, April 28, 1998). Evidence from boreholes also reveal that the water table has dropped significantly such that one now has to go very deep to get water, which was not the case in the past when the number of eucalyptus trees were few. It is important to point out here that the increase in the number of eucalyptus plantations actually started during the 1980s with the increased demand for telephone and electric poles. It was then that people resorted to the planting of the eucalyptus in valleys and stream banks where they could thrive because of water availability. The reduction in the volume of water has been devastating even for households particularly the inhabitants of Baba I, Bamunka and parts of Bamali who travel for about a kilometer to fetch potable water during the dry season. Despite all these problems, the discharge of the River Nun has remained perennial, although its volume fluctuates with seasons and years.

The Forest acts as a home for many medicinal plants, animal and insect species. Some wildlife species like the Tauraco banemani, phyllastrephus, poensis, viverra bivetta and a horst of others are becoming endangered. A greater portion of the land by the 1950s was under montane forest and savanna vegetation with long term bush fallowing and crop rotation. However, today, population growth with its attendant demand for farmland and settlement has led to a rapid loss of the forest value, especially on farmlands with short cycles of fallowing. The demand for water use either for irrigation (during the dry season), fishing and sand mining has increased though the present supply of fish has drastically dropped. A population growth rate of $2.5 \%$ indicated by data from Public Health Units on fertility, mortality as well as migration may be consistent with social conflicts experienced in the area. These social changes are indicated by the invasion of marginal lands and the resulting farmer-grazer conflicts during periods of transhumance.

To find out the perception of the local residents on the degradation of the watershed, 150 questionnaires were distributed to the sampled population on the dominant activities responsible for the degradation of the watershed, 122 people responded as shown on Table 1. The findings show that bush fires and farming cause the most damage to the watershed while no damage is registered for traditional practices. Activities such as bee farming, rearing livestock, wood carving, hunting and fuel wood extraction cause some damage to the watershed. Population increase and the introduction of beans, corn and irish potatoes farming, have been considerably responsible for forest depletion. Although the creation of the Kilum Mountain Forest Project in 1987 was aimed 
at checking the encroachment and destruction of the forest, this destructive tendency has continued. In addition, the incidence of the numerous forest fires which are either accidental or intentional simply add to the scope of the problem (Table 1). Hunting and fuel wood were judged to be causing some damage.

Table 1. Respondent's views on dominant activities degrading the Bamendjin Catchment Area and damage assessment rating

\begin{tabular}{ccccc}
\hline Livelihood & No. Respondents & High damage & Some damage & No damage \\
\hline Bee Farming & 15 & & $\checkmark$ & \\
Rearing Livestock & 16 & & $\checkmark$ & \\
Wood Carving & 16 & & $\checkmark$ & \\
Farming & 32 & $\checkmark$ & & $\checkmark$ \\
Traditional Practices & 06 & & $\checkmark$ & \\
Hunting & 11 & & $\checkmark$ & \\
Fuelwood harvesting & 08 & & & \\
Bush Fire & 18 & $\checkmark$ & & \\
Total & 122 & &
\end{tabular}

Source: Kometa, 2011.

\section{The Impact of Watershed Degration}

Based on data collected from the Upper Nun Valley Development Authority (UNVDA), the production of rice for example flourished between 1977 and the late 1980s. From the late 1980s to 2000, production dropped drastically due to physical, human and financial reasons. However, with recent innovations in farming methods and environmental conservation strategies, production has witnessed a slight increase. The drop in production was not y recorded for rice alone. Other crops recorded the same decline which also affected their prices in the local markets (Table 2). When vegetation is destroyed, the immediate result is the reduction in primary producers. This will trigger direct or immediate food shortages and consequently migration and death of some species of plants and animals. Since cleared vegetation is often burnt, most soil organisms are lost. Since the 1970s, Pygeum africanus (or Prunus africana) has been over-exploited depriving some animals species of an important food supply. This is because the fruits from the Pygemn tree are very important in the diet of some birds like Bannermas turaco, Preuss monkey and the banded wattle-eye (Platysteira laticinata). The massive exploitation of the prunus tree since the 1970s has threatened the existence of so many species of animals and birds forcing some to migrate into other regions. It is important to note that, the high number of trees, animals and birds identified in this region in the past was also due to the strong belief at the time that the forest was the shrine of the 'gods' and no one was allowed to enter and collect or kill any animals, birds or plants.

Table 2. Evolution in the prices (FCFA) of some basic commodities in the area from 1982 to present

\begin{tabular}{lllllllll}
\hline Crop type/ Year & 1982 & 1987 & 1995 & 2000 & 2005 & 2008 & 2010 & 2012 \\
\hline Rice (Bag) & 5000 & 6500 & 7500 & 8000 & 9500 & 14500 & 1600 & 16500 \\
Irish potatoes (Bucket) & 800 & 1000 & 1200 & 1200 & 1500 & 2000 & 2500 & 300 \\
Beans (Bucket) & 1000 & 1500 & 2000 & 2500 & 2500 & 3000 & 4500 & 6500 \\
Maize (corn) (Bucket) & 700 & 1000 & 1500 & 1700 & 2000 & 2200 & 2800 & 3500 \\
Huckleberry (Bag) & 800 & 700 & 900 & 1200 & 1500 & 2000 & 2500 & 4500 \\
Smoke Fish (Bucket) & 2500 & 3000 & 4500 & 6000 & 7500 & 7500 & 8000 & 8000 \\
\hline
\end{tabular}

Source: Kometa, 2012.

Not surprisingly, agriculture is the major employer and the major determinant of land use in the area (Table 1). Agriculture provides the primary income source for $95 \%$ of the households. Many households live close to the 
poverty line. In the early 1980 s for example, approximately $50 \%$ of total land area here was considered agricultural land and was used in the cultivation of temporary crops like maize, beans and Irish potatoes and by the year 2000, the amount of agricultural land had increased to $58 \%$ and was encroaching into the watershed area (Ref.). This expansion in land devoted to agriculture has largely involved the replacement of forest and permanent crops by annual crops. The expansion of vegetables in lieu of cereal crops in the area is also a result of the favourable price and trade policies.

A number of economic phenomena have helped to shape the observed pattern of land use, particularly the expansion of agriculture across the landscape and its intensification in certain locations. On the commodity side, prices have changed in a discernible way over time, favouring annual crops such as maize and vegetables over perennial crops. Trends in input prices have also been influential in determining crop mixes, as the major crops differ considerably in their employment of the factors. For these reasons, markets and national economic policies have played a key role in determining observed land use patterns in the watershed. An important implication of expanded farmlands has been a steady decline in forest cover, an increase in erosion and sedimentation and an increase in the use of pesticide. Traditional crops, cropping systems and farming practices in the watershed remain problematic in this regard, although some technical solutions to the challenges of upland farming show some promise.

The rate of erosion and loss of soil fertility in these high altitudes can be dictated from the poor crop yields and the consequent rise in food prices. Soils in the high altitude areas favour the production of Irish potatoes and beans as in the Oku area. If agriculture in the area is to be carried out on a sustainable basis, modern farming techniques should be implemented. However, erosion the steep slopes happens to be a blessing to the lowland regions particularly the Ndop Plain. The eroded sediments from the slopes increases soil fertility on the lowlands when they are deposited. The alluvial soils within the Ndop Plain have been intensively used for subsistence agriculture and paddy rice farming. The cultivation of a variety of crops in this area is thanks to this fertile soils. Consequently, some farmers in some of the highlands in this area have now shifted to the permanently flooded areas within the Ndop Plain where more crop cycles are possible (Kometa, 2011). It can therefore be stated that whenever nature is harsh for agricultural production on the intensely humanized hill slopes, there has been overwhelming compensation in the swampy lowlands (Lambi, 2001).

Runoff in this area generally attains high volume and intensity, since there is often greater overland flow on the bare surface areas. The topsoils which are washed and deposited in stream fill up the water hence reducing the capacity of the streams and enhancing the tendency for flooding. An analysis of the drainage morphology also reveals that flooding is also caused by the nature of the terrain and also since the soils down slope which easily get saturated. The regimes of the River Nun tributaries are sufficiently boosted by streams with sources from basaltic and trachytic substrata. This is because a substratum of either basalts or trachytes retains relative more water than the basement complex rocks. Such an influence of the substratum shortens the lag time to a peaked hydrograph and enhances flooding in the lowlands. Also, where there is sparse vegetation, torrential rainfall that suddenly raises the base flow on the impervious rocks will enhance rapid rise in the stream hydrographs leading to the production of floods downstream. The aggressive search for farmlands is another factor which compels people to cut down vegetation along stream channels. This is another contribution to the frequency of seasonal floods in the area.

Rice farms are often used for the cultivation of beans, vegetables such as cabbages and other leguminous crops in the dry season. This is so intense that nearly all of the wetlands are taken up for this activity leaving very little area for grazing. The small portions left are therefore overstocked and over grazed by cattle. Another indication of over-grazing on the gentle slopes of this region is the existence of the bracken fern. This is very common over rangelands because their roots can adapt and thrive on degraded areas. In consonance with the unfavourable socio-economic and environmental mechanism examined, a stable watershed will probably be achieved only by controlling the factors of degradation. To better manage and protect our watershed, there should first of all be the establishment and management of protected areas.

\section{Implications for Development or Discussion}

The degradation of natural resources is the greatest constraint to sustainable agricultural development in Bamendjin watershed area and Cameroon as a whole. The sustainable use and management of land resources can only be achieved by adopting methods that improve land quality, water and vegetation use. Therefore, the topography, soils, vegetation and land use have direct implications on the water resources and natural resources in general. Watershed degradation in the Bamendjin catchment area threatens the livelihood of millions of people and constrains their ability to develop a healthy agricultural and natural resource base. Increasing 
populations of people and livestock, particularly in this steep, mountainous watershed, is rapidly depleting the existing natural resource base because the soil and vegetation systems cannot support present levels of use. The overall indication is that, the carrying capacity of these lands is being exceeded. As populations continue to rise, the pressures on the kilum-Ijim forests, rangelands, and marginal agricultural lands lead to inappropriate cultivation practices, forest removal, and grazing intensities.

Recognizing the importance of watershed conservation and management, especially as the economy depends predominantly on agriculture, this area has received (over the last few decades) an increasing attention from the government of Cameroon, as well as from concerned international and regional organizations. In the past, this mountain forested watershed was a catchment area where clean fresh mountain water originated and flowed to feed the River Nun and other rivers that take their rise from it However, over the last three decades, pressure from population growth, deforestation and unaccetable agricultural practices, are all taking their toll on the watershed and putting the supply of fresh water at risk. Watersheds that are damaged pose serious problems to environments and people, both upstream and downstream. The cost of this damage can be seen in eroded soil, landslides, diminished water quality and quantity, loss of biodiversity and severe ecological imbalances. Today, this degrading natural system is among the greatest constraints to sustainable development in the Bamendjin catchment area. The need for the careful management and sustainable use of this natural resource base has never been greater.

Watershed management means putting in place systems that ensure land resources preservation and sustainable exploitation. The watershed management approach must integrate various aspects of forestry, agriculture, hydrology, ecology, soils, physical climatology and other sciences. The management should reflect a continuous and a participatory nature that subsumes the intents of the local communities and the improvement of their livelihoods. This approach could also be a coordinating framework for management that attempts to focus on public, private, community and individual efforts, toward addressing high priority land and water-related issues within this hydrologically-defined geographic area. Promoting integrated watershed development programmes through effective participation of local people is a key to preventing further ecological imbalance.

From a socioeconomic perspective, it should involve coordinating the actions of numerous land users who may have multiple conflicting objectives. In the past, watershed management in Cameroon as a whole was treated largely as a technical problem. However, the lack of attention to socio-economic complications undermined numerous projects because local communities refused to go along with technical plans that conflicted with their diverse interests. However, today greater attention is being given to the socioeconomic aspects of watershed management. It is now recognized that local people need to be involved in decision-making so that they can use their land, animals and other natural resources in a productive way without causing harm to water and soil resources. The intention is to ensure that environmental objectives are well integrated with local economic, social and cultural goals. This could be considered as an appropriate approach for addressing food security and poverty alleviation. Nevertheless, there is still a need for in-depth investigations, analyses and consultation among all stakeholders on several issues of concern, such as appropriate mechanisms for sharing results and lessons learned, appropriate participatory processes, technologies that can ensure sustainable development and natural resources management, the role of forests or forested watersheds in sustaining and protecting water supplies

Virtually all production generates some environmental damage in the form of pollution and/or natural resource depletion, and it follows that, other things being equal, such damage or depletion increases as an economy expands. It is well known, however, that the economy-environment relationship can be nonlinear - and indeed, non-monotonic, Changes in economic structure occurring in the course of economic growth, alters both the valuation and demand for environmental assets, and if sectors differ in their propensity to pollute or to use depletable resources, it follows that depletion rates will also change. For land and forest issues, this analytical approach enables research to move beyond trivially true assertions that deforestation and upland land degradation are the consequences of population pressure and 'market forces'. One thing that quickly becomes clear is that while total population growth in a country may justifiably be regarded to be beyond the reach of policy except in the very long run, its spatial distribution, and the incentives that upland populations face when making resource use decisions, are very heavily conditioned by government policies, both those directly targeting such populations and activities, and also those operating at the broadest level of the economy. 


\section{Conclusion}

The Bamendjin watershed holds much promise for the sustainable development and the sustenance of local livelihoods in the area. However, based on the rapid growth of the population, unsustainable farming and the land use practices, it is evidence that the watershed is under serious threat. The high levels of poverty and the over dependence on agricultural activities only go to worsen the situation. Given the present dispensation, the logical way forward remains the harmonious observation and management of this very crucial natural resource system. It is important that awareness be raised on the indicators of watershed degradation and the importance of watershed management. This will reflect an appropriate approach for the sustainable use and management of natural and agricultural resources. Institutional and organizational agreements should be enforced and better managed in order to ensure effectiveness in the watershed programmes. A balance between population and carrying capacity of upland watersheds must be achieved if we intend to protect and conserve some of our most valuable species. In a diversified relief watershed like ours which is fast degrading, significant policy and programme responses are needed and solutions must not ignore the basic needs of people living in the uplands of these environment. Incentives may be needed to drop existing land-use practices for environmentally acceptable and sustainable resource utilisation. Land tenure and the complexity of user rights that constrain the development of land use practices needed to stabilize forest and rangelands should be revisited. Finally, multiple use options employing agroforestry, production forests, protection of forests on critically steep slopes, stall feeding of animals, and other practices which provide needed goods and services without improving soil and water resources must be promoted in appropriate areas.

\section{References}

Barrow, C. J. (1995). Developing the Environment: Problems and Management (p. 313). Longman Scientificx and Technical, London.

FAO (Food and Agriculture Organization of the United Nations). (2001). Global Forest Resources Assessment 2000. FAO, Rome. Retrieved August 20, 2004, from www.fao.org/forestry/fo/fra/main/pdf/ main_report.zip

FAO Publication. (2000). Developing Participatory and Integrated Watershed Management: A Case Study of the FAO/Italy Inter-regional Project for Participatory Upland Conservation and Development (PUCD).

Global Water Partnership. (2008). Planning for a Water Secure Future. Lessons from Water Management planning in Africa, P. 9.

Humpery, M. T. (2006). Community Managed Water Supplies in Africa: Sustainable or dispensable? Oxford University Presss .

Lambi, C. M., \& Kometa, S. S. (2008). The Rehabilitation of Rice Cultivation in Ndop Plain, Upper Nun Valley of Cameroon. In Epasa Moto (Ed.), A Bilingual Journal of Arts, Letters and the Humanities, 3(1), 138-152. University of Buea, Cameroon.

Lambi, C. M., Kometa, S. S., \& Balgah, S. N. (2007). Dry Season Cultivation in the Babungo - Ndop Central Wetland Zone, Upper Nun Valley of Cameroon. Journal of Applied Social Sciences, 6(1 \& 2), University of Buea, Cameroon.

Lambi, C. M. (2001). The Impact of Human Activity on Land Degradation in some Highland Regions of Cameroon: Implications for Development. In Lambi, C. M. (Ed.), Environmental Issues, Problems and Prospects (pp. 111-113), Uniques Printers, Bamenda, Cameroon.

Lambi, C. M. (2001). Environmental Constraints and Indigenous Agricultural Intensification in Ndop Plain. In Lambi, C. M. et al. (Eds.), Reading in Geography (pp. 179-189), Uniques Printers, Bamenda, Cameroon.

Ndenecho, E. N. (2007). Upstream Water Resources Management Strategy and Stakeholder Participation, AGWECAMS Printers, Bamenda, Cameroon.

Ross, \& McGee. (2006). Conceptual Framework for Catchment-Scale Integrated Water Resource Management. The University of Queensland International Water Centre.

Timberlake, L. (1986). Africa in Crisis; The Causes, the Cures of Environmental Bankruptcy (p. 231), Earthscan, UED.

World Bank. (1992). World Development Report 1992: Development and the- Environment. The World Bank, Washington, DC.

World Bank. (2000). Watershed Management: A Review of the World Bank Portfolio (1990-1999). 
World Bank. (2003). World Development Report 2003: Sustainable Development in a Dynamic World. The World Bank, Washington, DC.

Zimmermann, T. (1996). A manual on Watershed Resources Management in the Western Highlands of Cameroon, Helvetas, Bamenda, Cameroon. 